\title{
Life Cycle Cost Analysis of Residential Power Backup Gasoline Generators in Nigeria
}

\author{
1NWANKWOJIKE, BN; *2NWOSU, JO; ${ }^{3}$ EGWUAGU, MO \\ ${ }^{I}$ Department of Mechanical Engineering, Michael Okpara University of Agriculture, Umudike \\ ${ }^{2}$ Department of Mechanical Engineering, Gregory University, Uturu, Nigeria \\ ${ }^{3}$ Department of Mechanical and Production Engineering, Enugu State University of Science and Technology, Enugu, Nigeria \\ *Corresponding AuthorEmail: jikeobodo@gmail.com; onyexcel@gmail.com; engregwuaguo@yahoo.com
}

\begin{abstract}
This study involves life cycle cost analysis of portable gasoline generator brands mostly used for home power back up in Nigeria to guide the citizens' choice during acquisition. A total of two thousand six hundred and twenty electric power generating sets sampled from seventeen cities in Nigeria were evaluated by direct observation/descriptive experimental design. The evaluation parameters include initial or procurement, operation and maintenance costs, fuel consumption rate, operation period and residual value. Results showed Tiger, Sumec, Elemax, Elepaq and Jinjing as the most patronized brands of portable gasoline generators for home power back up in Nigeria major cities while 0.8 and 2.2KVA constitute the most used power ratings of the generators. Also 0.8KVA Sumec and 2.2KVA Elemax were revealed as most cost effective due to their comparative low life cycle cost of $\mathrm{N} 26,810$ and $\mathrm{N} 39,820$ respectively.
\end{abstract}

DOI: https://dx.doi.org/10.4314/jasem.v23i12.26

Copyright: Copyright $(\subset) 2019$ Nwankwojike et al. This is an open access article distributed under the Creative Commons Attribution License (CCL), which permits unrestricted use, distribution, and reproduction in any medium, provided the original work is properly cited.

Dates: Received: 30 November 2019; Revised: 20 December 2019; Accepted: 23 December 2019

Keywords: Gasoline generator, life cycle cost, power back up, power outage

The benefits of backup generators in maintaining residential comfort and safety during public power blackouts cannot be over emphasized. According (HVAC, 2015), home backup generator offers home owner peace of mind because it ensure continuous operation of residential appliances during public power outage. Apart from portability, the first things to consider before procuring a backup generator for your home is the type of fuel source it will run on (Jerad, 2019). Lazar (2018) revealed that the choice of fuel for running a home generator is determined by readily available fuels sources in the user's area. Thus, the increasing influx of different brands of portable gasoline generators in Nigeria due to incessant public power outage in this country. Gasoline powered generators enjoy high patronage by the home owners and small business outfits because petrol is the most subsidized fossil fuel in in this country. Hence, Ugwu et al., (2012) revealed that gasoline generators exhibit low cost of power generation and exergy loss in Nigeria when compared with diesel and natural gas powered ones respectively. However, the conflicting views of manufactures and end users on the cost performance economy of different brands of portable gasoline generators used in Nigeria, call to question of the best among them.

Portable generators are preferred for home back up application because of their compactness and can be moved easily (Bryant, 2017). Honda, Tiger, Sumec Firman, Elepaq, Thermocool, Elemax, Jinjing and
Lutian constitutes common brands of portable gasoline generators used in Nigeria (Lewis, 2019). Although it is optioned that Honda, Thermocool and Elemax generators are effective, fuel efficient and durable, their initial costs are quite expensive while others are seem to be quite affordable, durable and cost less upfront during long-term use (Lewis, 2019). Since all these popular brand of gasoline generators claimed to be durable/cost performance efficient and their spare parts are readily available, there is need for their life cycle cost analysis (LCCA) if best among them will be obvious. Life-cycle cost analysis is a vital decision-making tool for determining most costeffective option among different competing alternatives when they are technically appropriate for implementation on the same grounds (Tim et al., 2018; MESA, 2003). It tracks and measures costs involved in all stage of a processor/product's life cycle from purchase, own, operate, maintain to disposal (SAE, 1995). Although application of life-cycle cost analysis in decision boarding Nigeria electrification is not new, most of the recent works compared only diesel and photovoltaic systems solar despite the ever increasing acquisition of gasoline generators by home users in this nation. Ugwuoke and Oparaku, (2004), showed from LCCA that photovoltaic systems compared to diesel generators are more cost-effective at low electrical -power ranged residential application in Nigeria. Otasowie and Ezomo (2014), also showed through this technique that it is cheaper to use generators than National grid in powering base 
transceiver stations in Nigeria when back cost is considered. Oti and Lewachi (2017), revealed local production of PV components for cost effective adoption of solar PV systems for off-grid electricity generation. Therefore the comparative analysis of life cycle cost of mostly used brands of portable gasoline generators for home power back up in Nigeria in this study to guide the citizen choice during acquisition.

\section{MATERIALS AND METHODS}

This study involved life cycle cost analysis of mostly used brands of portable gasoline generators for home power back up in Nigeria. Two thousand six hundred and twenty (2620) sets of 0.8 and $2.2 \mathrm{KVA}$ generators that have been used between three to four years were sampled from seventeen Nigerian cities Aba, Abeokuta, Abuja, Afikpo, Asaba, Awka, Benni-city, Calabar, Enugu, Ikot-ekpene, Ibadan, Lagos, Lokoja, Owerri, Port-Harcourt, Umuahia, and Uyo. The brand of generators studied are Tiger, Sumec, Elemax, Elepaq and Jinjing because their availability is common in all the cities sampled. Initial or procurement, operation and maintenance costs, fuel consumption rate, operation period and residual value were evaluated as per each generator sampled using direct observation/ descriptive experimental design. The mean of these evaluation parameters as per each brand/power rating of the generators were determined and used for their life cycle cost analysis. The life cycle cost (LCC) of each generator brand/power rating was computed from the following relations given by (Peurifoy and Schexnayder, 2002), and compared using Analysis of Variance.

$$
\begin{aligned}
& L C C=O_{c}+C_{y} \\
& O_{c}=\left(C_{i}-V_{s}\right) A_{p}+i\left(V_{s}\right) \\
& V_{s}=C_{i}+m(t)-C_{n} \\
& A_{p}=A\left[P(1+i)^{n}\right.
\end{aligned}
$$

$C_{y}=n C_{o m} N_{m}$

$\dot{F}=f_{c} P_{g e n}$

Where; $O_{c}=$ Ownership cost; $C_{i}=$ initial cost; $V_{s}=$ Salvage value; $m(t)=$ maintenance cost for $\mathrm{n}$ period; $C_{y}=$ Operation and maintenance cost per year; $C_{o m}=$ Operation and maintenance cost per month, $N_{m}=$ Number of month equipment operated in a year; $n=$ Number of years, $i=$ Interest rate, $\dot{F}=$ Fuel consumption rate, $f_{c}=$ fuel consumed per power generated by the generator, (lit $/ \mathrm{kWh}), P_{\text {gen }}=$ power output of the generator, $(\mathrm{kW})$

\section{RESULTS AND DISCUSSION}

The results of this investigation shown in Table 1 revealed significant variations in initial, residual, operation/maintenance and ownership costs of the five brands of portable gasoline generators mostly used by home owner in seventeen Nigeria cities sampled. The initial, residual, operation/maintenance and ownership costs of the low power rated plants were lower than those of high plants as expected. The initial cost of Elepaq is the highest among all brands of generators while those of Sumec and Elemax constitute the lowest among $0.8 \mathrm{KVA}$ and $2.2 \mathrm{KVA}$ respectively. It is also obvious from this table that fuel consumption rates of low power rated (0.8KVA) generators are higher than those of 2.2KVA while Sumec constitutes the highest fuel consumed brand irrespective of the power rating. Tiger and Elemax's fuel consumption rate of $1.39 \mathrm{~L} / \mathrm{kWh}$ constitutes the lowest among $0.8 \mathrm{KVA}$ generators while $0.66 \mathrm{~L} / \mathrm{kWh}$ of Elemax and Elepaq is the lowest among the 2.2KVA plants. Thus Elemax generators exhibited least life cycle cost of $\mathrm{N} 39,820$ among the five brands of 2.2KVA generators investigated. Life cycle cost of Sumec $(\mathrm{N} 26,810)$ is the least among the $0.8 \mathrm{KVA}$ generators despite its high

\begin{tabular}{|c|c|c|c|c|c|c|c|c|c|c|}
\hline & \multicolumn{5}{|c|}{ 0.8 KVA } & \multicolumn{5}{|c|}{2.2 KVA } \\
\hline & Tiger & Sumec & Elemax & Jinjing & Elepaq & Tiger & Sumec & Elemax & Jinjing & Elepaq \\
\hline Initial cost $(\mathrm{N})$ & 16800 & 14500 & 15600 & 17500 & 17600 & 23400 & 46200 & 20400 & 45200 & 49000 \\
\hline $\begin{array}{l}\text { Operation time per } \\
\text { year }(h r s)\end{array}$ & 4825 & 1460 & 4825 & 1460 & 4825 & 2190 & 3285 & 1460 & 4825 & 2190 \\
\hline $\begin{array}{l}\text { Fuel consumed per } \\
\text { power generated, } f_{c} \\
\text { (lit/Kwh) }\end{array}$ & 1.39 & 1.67 & 1.39 & 1.41 & 1.40 & 0.76 & 0.91 & 0.66 & 0.76 & 0.66 \\
\hline $\begin{array}{l}\text { Residual value, } V_{s} \\
\text { (\#) }\end{array}$ & 8700 & 7800 & 8800 & 8000 & 8500 & 13100 & 20400 & 14600 & 20000 & 24000 \\
\hline $\begin{array}{l}\text { Operation/maintena } \\
\text { nce cost per year, } \\
C_{y}(\AA)\end{array}$ & 11640 & 11640 & 17880 & 16320 & 15000 & 19440 & 30360 & 18840 & 27120 & 20640 \\
\hline $\begin{array}{l}\text { Ownership cost, } O_{c} \\
\text { (\#) }\end{array}$ & 17610 & 15170 & 16280 & 18450 & 18510 & 24430 & 48780 & 20980 & 47720 & 51500 \\
\hline Life cycle cost, (\#) & 29250 & 26810 & 34160 & 34770 & 33510 & 3870 & 79140 & 39820 & 74840 & 72140 \\
\hline
\end{tabular}
fuel consumption rate because of its lowest initial, operation/maintenance and ownership costs.

Table 1: Life cycle cost analysis of mostly used brands of portable gasoline generators in Nigeria 
Conclusion: This study revealed Tiger, Sumec, Elemax, Elepaq and Jinjing as the most patronized brands of portable gasoline generators for home power back up in Nigeria major cities while $0.8 \mathrm{KVA}$ Sumec and 2.2KVA Elemax constitute the most cost effective.

\section{REFERENCE}

Bryant, J (2017). The Benefits of using Portable Generators. https://www.toolforhome.com. Accessed on April 29, 2017.

HVAC (2015). The Endless Benefits of Having a Home Backup Generator. https://www.sosxtremecomfort.com. Accessed on July 20, 2015

Jerad, G (2019). How to Pick the Perfect Home Standby Generator. Home Standby Generator Buyer's Guide. https://www.electricgeneratorsdirect.com/generat or-product-expert.php

Lazar, R. (2018). Home Generators Basics: Standby Whole House and Portable GeneratorsComparison, Reviews, Selection Guide. Https://Www.Smps.Us/Home-Generators.Html

Lewis, R (2019). Best Generator Brands in Nigeria. NaijaTech Guide Team. https://www.naijatechguide.com/2019/01/bestgenerator-brands-nigeria.html

MESA -Maintenance Engineering Society of Australia (2003). "A Life Cycle Cost Summary". Paper presented at International Conference of Maintenance Societies (ICOMES, 2003). May 20-23. Sheraton Hotel Perth, Western Australia, Australia
Otasowie PO; Ezomo PI (2014). Life Cycle Cost Analysis of Diesel Generator Set and National Grid in Nigeria. Journal of Emerging Trends in Engineering and Applied Sciences (JETEAS) 5(5): $363-367$

Oti, OF; Lewachi, AA (2017). Analysis of Economic Viability of Solar Photovoltaic Systems for Small Scale Off-Grid Electricity Generation in Nigeria. Umudike Journal of Engineering and Technology, Vol. 3, No. 1. pp. $36-44$.

Peurifoy, R; Schexnayder, C; (2002). Construction Planning, Equipment, and Methods. Sixth edition, McGraw-Hill, New York

SAE -Society of Automotive Engineers (1995). "Life Cycle Cost", Reliability, Maintainability, and Supportability Guidebook, 3rd edition, Warrendale, PA

Tim M; Larry, M; Michael, M; Nathan, C (2018). Life Cycle Cost Analysis Hand Book. 2 $2^{\text {nd }}$ Edition. State of Alaska, Department of Education \& Early Development Juneau, Alaska

Ugwu, HU; Nwankwojike, BN; Ogbonnaya, EA; Ekoi, EJ (2012). Energy and Economic Losses due to Constant Power Outages in Nigeria. Nig. J. Technol. 31. 2. 181-188

Ugwuoke, PE; Oparaku OU (2004). Comparative Life-Cycle Cost Analysis of Solar Photovoltaic Power System and Diesel Generator System for Remote Residential Application in Nigeria Global J. Engineer. Res.3 (1\&2) 2004: 9-15. 